\title{
Severe Coombs positive autoimmune haemolytic anaemia associated with ulcerative colitis
}

\author{
M.A. Wodzinski and A.C.K. Lawrence \\ Department of Haematology, Northern General Hospital, Sheffield, S5 7AU
}

\begin{abstract}
Summary: We describe a case of severe autoimmune haemolytic anaemia developing in newly diagnosed ulcerative colitis of moderate severity. Full immunosuppression with steroids and azathioprine failed to bring about a full remission and a splenectomy was performed which resulted in a remission enabling immunosuppression to be discontinued. This case is compared with three previously described cases of autoimmune haemolytic anaemia associated with severe colitis requiring splenectomy.
\end{abstract}

\section{Introduction}

Ulcerative colitis, a condition considered to have an immune aetiology, is frequently complicated by anaemia. This anaemia is usually ascribed to iron depletion secondary to haemorrhage, or to impaired haemopoiesis related to inflammation or infection, but rarely an autoimmune haemolytic anaemia can occur (Allan et al., 1983). In a series of 624 patients with ulcerative colitis only one had a Coombs positive autoimmune haemolytic anaemia (Edwards \& Truelove, 1964). Occasionally a severe anaemia can result; such a case is described here.

\section{Case report}

A 63 year old man presented with loose motions mixed with blood, opening his bowels four times a day. A diagnosis of ulcerative colitis was made on sigmoidoscopy, and treatment was commenced with sulphasalazine $0.5 \mathrm{~g}$ four times a day and hydrocortisone enemas. The haemoglobin was $11.0 \mathrm{~g} / \mathrm{dl}$, and ESR $70 \mathrm{~mm}$ in the first hour (Westergren).

Three months later he felt listless, the haemoglobin was $10.9 \mathrm{~g} / \mathrm{dl}$ and a blood film showed spherocytes and polychromasia. The reticulocyte count was $0.19 \times 10^{12} / 1$. The direct antiglobulin test was strongly positive (IgG mainly with some C3d; no specificity could be found). The sulphasalazine was discontinued and prednisolone $45 \mathrm{mg} / \mathrm{d}$ started and gradually tapered to $15 \mathrm{mg}$ daily. A bowel relapse necessitated an increase to $30 \mathrm{mg} / \mathrm{d}$.

M.A. Wodzinski, M.B., M.R.C.P.; A.C.K. Lawrence, M.D., F.R.C.Path.

Accepted: 18 April 1984
One month later he became tired and dyspnoeic. He continued to open his bowels three to four times daily. His haemoglobin had fallen to $7.9 \mathrm{~g} / \mathrm{dl}$ with a reticulocyte count of $0.33 \times 10^{12} / 1$, total white cell count $8.8 \times 10^{9} / 1$ with a normal differential, platelet count $610 \times 10^{9} / 1$. Electrolytes and calcium were normal. Total protein $55 \mathrm{~g} / \mathrm{l}$, albumin $34 \mathrm{~g} / \mathrm{l}$, bilirubin $35 \mu \mathrm{mol} / 1(2.0 \mu \mathrm{g} / \mathrm{dl})$, alkaline phosphatase $81 \mathrm{IU} / 1$ (normal 25-120 IU/1), lactate dehydrogenase 992 IU/1. (normal 115-480 IU/1), aspartate transaminase $36 \mathrm{IU} / 1$ (normal 5-45 IU/1), alanine transaminase $36 \mathrm{IU} / 1$ (normal 5-42 IU/1), ferritin $657 \mu \mathrm{g} / 1, \mathrm{~B}_{12}$ $197 \mathrm{ng} / 1$, normal folate $5.8 \mu \mathrm{g} / 1$, autoimmune antibody screen negative. Immunoglobulins: $\operatorname{IgG} 8.1 \mathrm{~g} / 1, \operatorname{IgA}$ $1.0 \mathrm{~g} / \mathrm{l}$, IgM $0.7 \mathrm{~g} / \mathrm{l}$. No monoclone present. Stool culture was negative. Sigmoidoscopy showed active colitis with ulceration and pseudopolyp formation. Biopsies taken at $20 \mathrm{~cm}, 30 \mathrm{~cm}$ and $40 \mathrm{~cm}$ showed active colitis.

He was treated with prednisolone $90 \mathrm{mg}$ daily, azathioprine $100 \mathrm{mg}$ daily and blood transfusion. He continued to require transfusions every ten days, and after three weeks a decision to perform elective splenectomy was made. This was delayed by episodes of septicaemia and herpetic infection of the lips which were treated with the appropriate antimicrobials. The steroid dose was reduced and the azathioprine was stopped.

A splenectomy was performed six weeks after admission. He developed a pulmonary embolus postoperatively for which he was anticoagulated. He has not required any further blood transfusions since, and the dose of steroids has been gradually tailed off. Two months post splenectomy he was well, opening his bowels twice daily, the prednisolone having been reduced to $10 \mathrm{mg}$ daily. The direct antiglobulin test 
remained positive and his haemoglobin had risen to $12.6 \mathrm{~g} / \mathrm{dl}$.

\section{Discussion}

Six cases have previously been described in which a splenectomy has been performed for severe autoimmune haemolytic anaemia associated with ulcerative colitis (Altman et al., 1979; Lorber et al., 1955; Keene, 1966; Lorst et al., 1975). Other cases (Altman et al:, 1979) have responded to steroids alone, required azathioprine as well, or have had colectomy performed for bowel symptoms leading to a remission of haemolysis.

Of the splenectomy cases, two did not have colitis at the time (Keene et al., 1966; Lorst et al., 1975) and one with inactive colitis did not receive a trial of medical treatment (Lorber et al., 1955). Three splenectomy

\section{References}

ALLAN, R.N., KEIGHLEY, M.R.B., ALEXANDERWILLIAMS, J. \& HAWKINS, C. (eds) (1983), Inflammatory Bowel Disease, p. 121. Churchill Livingstone: Edinburgh.

ALTMAN, A.R., MALTZ, C. \& JANOWITZ, H.D. (1979). Autoimmune haemolytic anaemia in ulcerative colitis. Digestive Diseases and Sciences, 24, 282.

EDWARDS, F.C. \& TRUELOVE, S.C. (1964). The course and prognosis of ulcerative colitis. Part III. Complications. Gut, 5, 1. cases are thus described which had active colitis and received a trial of medical treatment (Altman et al., ํㅡㄱ 1979). In one case associated with severe colitis there $\Phi$ was a total failure of medical treatment and splenec- $\frac{a}{c}$ tomy was combined with colectomy resulting a complete remission. A second case made a partial response $\stackrel{\rho}{\rightarrow}$ to steroids, made a further response to splenectomy, but required azathioprine to bring about a complete remission. A third case, a relapsed colitic, made a $\frac{\bar{\rho}}{\bar{c}}$ partial response to steroids, and a complete response $\stackrel{\mathbb{Q}}{\propto}$ to splenectomy.

Our case had colitis of moderate severity and $\stackrel{\text { s }}{\circ}$ received a trial of full medical treatment, but unfortunately developed the complications of immunosuppres- $\vec{\omega}$ sion before a splenectomy could be performed. It is $\stackrel{ }{\circ}$ suggested that if autoimmune haemolysis persists despite heavy immunosuppression early consideration 3 . should be given to splenectomy.

GORST, D.W., LEYLAND, M.J. \& DELAMORE, I.W. (1975). Autoimmune haemolytic anaemia and ulcerative colitis. Postgraduate Medical Journal, 51, 409.

KEENE, W.R. (1966). Uncommon abnormalities of blood $\stackrel{\widehat{\supset}}{\supset}$ associated with chronic ulcerative colitis. Medical Clinions $\vec{\varphi}$ of North America, 50, 535.

LORBER, M., SCHWARTZ, L.I. \& WASSERMAN, L.R. (195 Association of antibody coated red blood cells wi ulcerative colitis. American Journal of Medicine, 19, 88. 